\title{
Adipose derived mesenchymal stem cells harvesting
}

\author{
Palencar $\mathrm{D}^{1}$, Dragunova $\mathrm{J}^{2}$, Hulin $\mathrm{I}^{1}$, Koller $\mathrm{J}^{2}$ \\ Department of Plastic Surgery, School of Medicine, Comenius University, Bratislava, Slovakia. \\ drahomir@palencar.sk
}

\begin{abstract}
BACKGROUND: The lipografting is increasingly used in the field of plastic surgery. Widely used harvesting technique of fatderived stem-cells is lipoaspiration. There exist two big streams of fat harvesting for lipografting: mechanical liposuction and manual liposuction.

METHODS: Two harvested specimens were compared in this prospective blind study in the means of stemcells viability and their ability to grow in cell-cultures. Techniques to compare were: manual lipoaspiration with $50 \mathrm{ml}$ syringe and WAL (water-jet assisted liposuction).

RESULTS: Twenty specimens from ten patients were investigated in the tissue bank. There were no differences in the amount of live stem-cells between two groups. Also no differences were found between both harvesting techniques in the mean of cell ability to grow in cell-cultures.

CONCLUSION: It can be concluded that there are no statistically significant differences in the number, vitality and viability of stem cells when comparing two ways of mesenchymal stem cell collection, both manual and machine sampling (WAL). When cultured in vitro, both samples collected from each patient also appeared to be able to multiply with no statistical differences (Tab. 2, Fig. 2, Ref. 18). Text in PDF www.elis.sk. KEY WORDS: lipograft, mesenchymal stem cells, WAL, manual lipoaspiration, regenerative medicine.
\end{abstract}

\section{Introduction:}

Nowadays, the clinical use of mesenchymal stem cells is widespread. But despite the relatively broad clinical use, there are still diverse views on the way and technique of ADMSCs (adipose derived mesenchymal stem cells) collection $(1,2,3)$. Some authors recommend taking them manually, using syringes of different calibre. Others use liposuction devices with precisely controlled vacuum.

Recent reports have identified adipose tissue as the tissue in the body that contains the highest percentage of adult stem cells $(4,5)$. These ADMSCs can undergo multilineage differentiation (5-13) and may be crucial for fat graft take since mature adipocytes that survive harvesting procedures will not replicate and will eventually die, generating harmful inflammatory responses (14). ADMSCs are found in subdermal adipose tissue. In liposuction, there are a number of cellular elements in the liposuctate. One of the cell types taken from liposuction is also mesenchymal stem cells, so they are called fat derived. Today, mesenchymal stem cells are considered to be only one of the components of the success of lipografting or lipofilling. Other factors also influence lipotransfer efficiency, but the presence of ADMSCs remains key.

${ }^{1}$ Department of Plastic Surgery, School of Medicine, Comenius University, Bratislava, Slovakia, and ${ }^{2}$ Department of Burns and Reconstructive Surgery, School of Medicine, Comenius University, Bratislava, Slovakia

Address for correspondence: D. Palencar, PhD, MD, Department of Plastic Surgery, Faculty of Medicine, Comenius University in Bratislava, Ruzinovska 6, SK-826 06 Bratislava, Slovakia.

Phone: +0903424096
In the presented study, two ways of sampling lipograft for the presence of ADMSCs in liposuctate are compared. The presence of mesenchymal stem cells in the lipograft still plays a fundamental role in assessing the survival of lipograft.

\section{Method}

The presented study was designed as a blind prospective study. The collected liposuctate in aesthetic liposuction was sent to the tissue bank of the Burns and Reconstructive Surgery Department of the Medical Faculty of Comenius University in Bratislava, where it was further processed and assessed by the tissue bank staff. The study was designed so that a tissue bank evaluator could not influence the results of the study by his subjective opinion. In the study, randomly selected patients were used, that came for abdominal liposuction for aesthetic reasons. The removed liposuctate was immediately sent for processing to a tissue bank after surgery. All patients signed an informed consent to participate in the study. Tissue samples were destroyed at the end of the study.

In the planned liposuction, the suction area was first infiltrated with a tumescent solution (that contained epinefrin) using a 50-ml syringe with a sharp needle $(0.7 \mathrm{~mm}$ in diameter, $250 \mathrm{~mm}$ length). Then $50 \mathrm{ml}$ of liposuctate was collected into a $50 \mathrm{ml}$-syringe using a $3 \mathrm{ml}$ cannula according to Coleman. Subsequently, the water-jet aesthetic liposuction was continued. After infiltration with a waterjet tumescent solution (with epinefrin), liposuction was performed in a total volume of 1000 to $3000 \mathrm{ml}$. The vacuum was set at 300 $\mathrm{mmHg}$. A $3 \mathrm{~mm}$ diameter cannula was ingested. Of the final liposuctate, $50 \mathrm{ml}$ of liposuctate was collected and sent for processing to a tissue bank together with the first sample. Tissue bank workers 
Tab. 1. Number of stem cells and vitality

\begin{tabular}{|c|c|c|c|c|c|c|}
\hline \multirow{2}{*}{ Patient } & \multicolumn{3}{|c|}{ Manual harvesting } & \multicolumn{3}{|c|}{ Water-jet harvesting } \\
\hline & $\mathrm{ADSCs}^{1}$ & Vitality $(\%)^{2}$ & $\mathrm{ADSCs} / 5 \mathrm{~d}^{3}$ & $\mathrm{ADSCs}^{1}$ & Vitality $(\%)^{2}$ & $\mathrm{ADSCs} / 5 \mathrm{~d}^{3}$ \\
\hline 1 & 25,000 & 93.60 & $2,800,000$ & 30,000 & 95.20 & $3,100,000$ \\
\hline 2 & 12,000 & 95.00 & $2,600,000$ & 13,000 & 94.20 & $2,400,000$ \\
\hline 3 & 95,000 & 94.50 & $5,700,000$ & 80,000 & 93.30 & $5,900,000$ \\
\hline 4 & 40,000 & 93.20 & $2,700,000$ & 42,000 & 94.50 & $3,300,000$ \\
\hline 5 & 125,000 & 93.40 & $6,300,000$ & 150,000 & 95.60 & $5,400,000$ \\
\hline 6 & 41,000 & 95.70 & $5,800,000$ & 31,000 & 96.10 & $5,600,000$ \\
\hline 7 & 50,000 & 95.10 & $2,900,000$ & 48,000 & 94.80 & $3,100,000$ \\
\hline 8 & 90,000 & 95.70 & $5,400,000$ & 78,000 & 94.90 & $5,800,000$ \\
\hline 9 & 100,000 & 93.80 & $5,400,000$ & 113,000 & 94.90 & $5,300,000$ \\
\hline 10 & 87,000 & 94.30 & $5,980,000$ & 94,000 & 94.50 & $5,650,000$ \\
\hline
\end{tabular}

${ }^{1}$-ADSCs-number of adiposederived stem cells in $1 \mathrm{ml}$ of lipoaspirate, ${ }^{2}-$ Vitality of ADSCs $(\%)$ after harvesting, ${ }^{3}-$ ADSCs/5d: number of ADSCs in $1 \mathrm{ml}$ after 5 days cultivation

Tab. 2. Mean value of stem cells and vitality.

\begin{tabular}{lccc}
\hline Technique & ADSCs $/ 1 \mathrm{ml}^{1}$ & ${\text { Vitality }(\%)^{2}}^{2}$ & ADSCs $/ 5$ days $^{3}$ \\
\hline Manual harvesting & 66,500 & 94.43 & $4,558,000$ \\
WAL harvesting & 67,900 & 94.80 & $4,555,000$ \\
& $\mathrm{p}=0.723$ & $\mathrm{p}=0.336$ & $\mathrm{p}=1.000$ \\
\hline
\end{tabular}

${ }^{1}$ - Mean value of ADSCs in $1 \mathrm{ml}$ of lipoaspirate, ${ }^{2}-$ Mean value of vitality after harvesting, ${ }^{3}$ - Mean value of ADSCs in $1 \mathrm{ml}$ after 5 days cultivation

were unaware of which particular sample was derived from manual or machine-assisted liposuction (WAL- water-jet assisted liposuction). The samples were identified by the patient's sequential number and $\mathrm{A}$ or $\mathrm{B}$.

After immediate delivery of the samples to the tissue bank, these were processed as follows: For every isolation $50 \mathrm{ml}$ of lipoaspirate was used. The lipoaspirate was washed 3 times by $0.9 \%$ saline solution, subsequently Clostridium histolyticum derived Collagenase $(100 \mu \mathrm{g} / \mathrm{ml})$ was added for $90 \mathrm{~min}$. The detached cells were separated from the enzymatically digested fat tissue by centrifugation $(1500 \mathrm{rpm} / 5 \mathrm{~min})$. The erythrocytes from the sediment were separated by the osmotic lysis due to a effect of distillated water (Aqua pro injectione). Distillated water was added to a sediment ( $1: 1$ volume) for 60 second, subsequently $2 \mathrm{x}$ times concentrated medium (D-MEM without any supplements, without serum) 1:1 (volme per volume) to equalized the osmotic

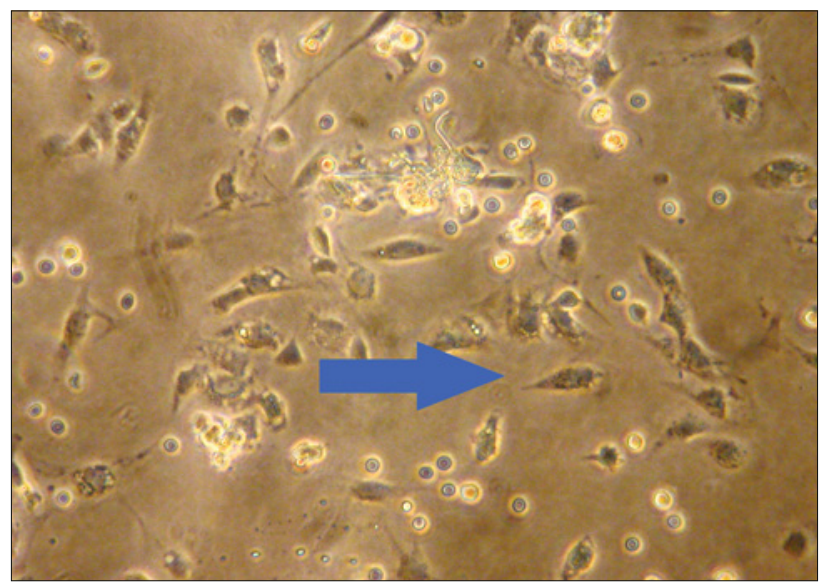

Fig. 1. Mmicroscopic view of processed lipoaspirate, arrow = mesenchymal stem cell. presure was added, the mixture was centrifuged (1500 rpm/ $5 \mathrm{~min}$ ) and the separated cells were suspended in a cultivation medium $(5 \mathrm{ml}$ ), the cells were counted in a Burker chamber (for 1 sample 3 independent counting were performed and arithmetic average was estimated) and seeded into a cultivation flasks (Sarstedt, $75 \mathrm{~cm}^{2}$, air-vent flasks for tissue cultures). Cultivation was provided at $37^{\circ} \mathrm{C}$ in $\mathrm{CO}_{2}$ incubator for 5 days to reach the confluency.

Individual samples were evaluated for the number of mesenchymal stem cells immediately after collection and after five days of culture. Their vitality and their ability to multiply in cell cultures were assessed.

The results of ADMSCs assessment were statistically processed using Student t-test.

\section{Material}

Patients arriving for abdominal liposuction for aesthetic reasons were included in the study. The number of patients was ten. All patients were healthy, without disease, with a negative history, did not take any medication. None of the patients underwent liposuction in the past. All patients had only abdominal liposuction. These were patients aged 26 to 41 years, with an average age of 32.4 years. Of the ten patients, there was one man. All patients

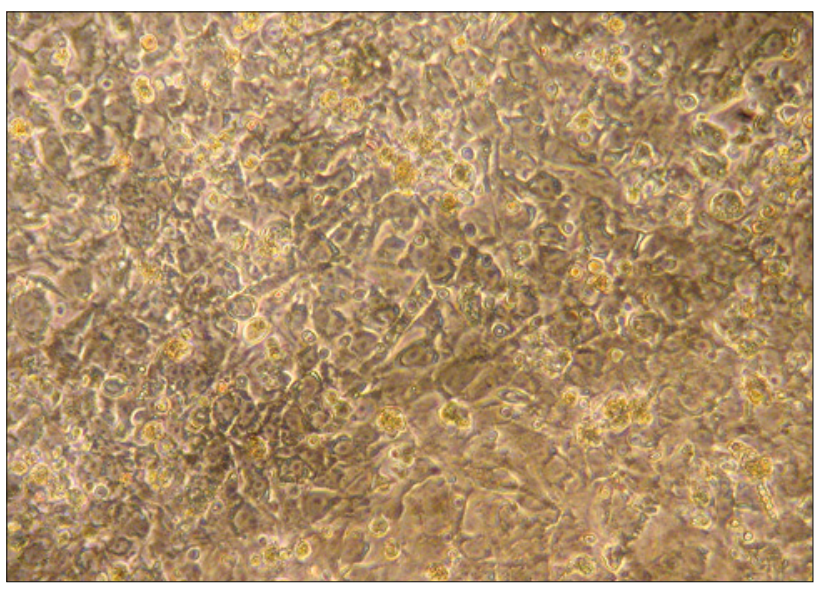

Fig. 2. Microscopic view after 5 days culturing, confluency of stem cells. 
signed an informed consent to participate in the study. Samples were discarded after study termination.

\section{Results}

After processing and counting of the lipoaspirates immediately after collection, the ADMSCs counts from 12,000 per $1 \mathrm{ml}$ to 125,000 per $1 \mathrm{ml}$ in the manual collection group, while in the water-jet assisted liposuction (WAL) group the numbers were from 13,000 per $1 \mathrm{ml}$ to 150,000 per $1 \mathrm{ml}$. The sample's vitality was above $93 \%$ in both groups. After five days of culture, all samples were compared and the number of ADMSCs was practically uniform in both groups ranging from 2,400,000 to $6,300,000$ cells per $1 \mathrm{ml}$.

Based on the ADMSCs in individual samples, no statistical differences in cell numbers were found when comparing two sampling techniques $(p=0.723)$. Similarly, no statistical differences were found in cell vitality $(p=0.336)$. When ADMSCs were compared after five days of cultivation, no statistical differences were also found (p 1,000) (Tabs 1 and 2).

On average, 66,500 stem cells per $1 \mathrm{ml}$ were withdrawn by manual aspiration or WAL. That means that, an average of 66 million mesenchymal stem cells could be taken up in a $1000 \mathrm{ml}$ liposuction. The images show a microscopic view of the samples immediately after taking (Fig. 1) and after five days of cultivation (Fig. 2). The second picture clearly shows the confluency and multiplication of mesenchymal stem cells.

\section{Discussion}

There are not many comparative studies available in the literature, that monitor the different techniques of liposuctate collection with respect to the presence and vitality of mesenchymal stem cells. It is true that there is not still widely accepted methodology for the collection of lipograft for the purposes of regenerative and aesthetic medicine. Some studies compare PAL (power assisted liposuction) at different vacuum values. In other studies, PAL is compared with manual aspiration. However, most studies work with a small number of patients, often from three to nine patients.

Only one study refers the results of liposuctate comparisons from 15 patients. Charles de Sa et al presents a comparative study in 15 healthy men and women aged 25-60 years, undergoing abdominal cosmetic surgery (15). Samples underwent histological analysis in order to verify the integrity and functionality of harvested adipocytes and ADSCs (adiposederived stem cells). Comparison was between manual aspiration $(275,394$ and $550 \mathrm{mmHg}$ ) and PAL (350 and $700 \mathrm{mmHg}$ ). Values of negative pressure produced by syringes as well as pressures of 350 and $700 \mathrm{mmHg}$ obtained by PAL did not lead to differences in the number of adipocytes and viability of the ADSCs extracted. That is in contrast to other studies that showed superiority of low pressure aspiration $(16,17)$.

Cheriyan et al compared the use of a high vacuum of 760 $\mathrm{mmHg}$ and a low vacuum of $250 \mathrm{mmHg}$ at PAL. Abdominal lipoaspiration was performed on 3 patients on the opposite side of the flank after infiltration with tumescent solution. Adipocyte survival and cell viability were measured in vitro. Adipocyte count was $47 \%$ higher when aspirated at low pressure compared to high pressure, immediately after harvesting. Cell viability was significantly higher at day 7 with low-pressure aspiration (17).

In Bony et al WAL of $375 \mathrm{mmHg}$ was compared by manual aspiration with a vacuum of $290 \mathrm{mmHg} .8$ women were included in the study and the two techniques were used for each patient. The lipoaspirates of subcutaneous abdominal fat were collected on both side of the umbilicus in each patient. In vitro analysis: cell yield, viability and immunophenotype of the SVF (stromal vascular fraction). Osteogenic and adipogenic differentiation and immunosuppressive capacity of ADSCs (adiposederived stem cells) was assessed in vitro. In vivo analysis was observed immunosuppressive capacity of ADSCs during a delayed-type hypersensitive response model in mice. Equivalent number of viable cells, fibroblast colony- forming units and immunophenotype were observed. Interestingly, ADSCs isolated from manual liposuctions showed significantly higher immunosuppressive potential than those from WAL in vitro but not in vivo (18).

Mojallal et al compared manual liposuction with PAL (power sister liposuction) with pressure $350 \mathrm{mmHg}$ and $700 \mathrm{mmHg}$ (16). They harvested trochanteric fat from 3 healthy patients aged 36, 43 and 58 years. Number of isolated SVF cells was assessed. Cell yield with a pressure of $350 \mathrm{mmHg}$, power assisted or manual liposuction, was higher than that obtained at $700 \mathrm{mmHg}$. Cell yield with PAL $(350 \mathrm{mmHg}$ ) was significantly superior to aspiration with a syringe $(p<0.05)$. But this study is limited to only three patients.

\section{Conclusion}

It can be concluded that there are no statistically significant differences in the number, vitality and viability of stem cells when comparing two techniques of mesenchymal stem cell collection, both manual and machine sampling (WAL). Stem cell counts were comparable in both groups and so their vitality. When cultured in vitro, both samples collected from each patient also appeared to be able to multiply with no statistical differences.

\section{References:}

1. Tabit CJ, Slack GC, Fan K, Wan DC, Bradley JP. Fat grafting versus adiposederived stem cell therapy: distinguishing indications, techniques, and outcomes. Aesthet Plast Surg.2012; 36 (3): 704-713.

2. Bourin P, Bunnell BA, Casteilla L et al. Stromal cells from the adipose tissuederived stromal vascular fraction and culture expanded adipose tissuederived stromal/stem cells: a joint statement of the International Federation for Adipose Therapeutics and Science (IFATS) and the International Society for Cellular Therapy (ISCT). Cytotherapy 2013; 15 (6): 641-648.

3. Tocco I, Widgerow AD, Lalezari S et al. Lipotransfer: the potential from bench to bedside. Ann Plast Surg 2014; 72 (5): 599-609.

4. Bellini E, Grieco MP, Raposio E. The science behind autologous fat grafting. Ann Med Surg 2017; 24: 65-73.

5. Baer PC, Geiger H. Adipose-derived mesenchymal stromal/stem cells: tissue localization, characterization, and heterogeneity. Stem Cell Int 2012; (2012): 1-11. 
6. Zuk PA, Zhu M, Mizuno $\mathbf{H}$ et al. Multilineage cells from human adipose tissue: implications for cell-based therapies. Tissue Eng 2001; 7 (2): 211-228.

7. Zuk PA, Zhu M, Ashjian P et al. Human adipose tissue is a source of multipotent stem cells. In: Raff M (Ed). Mol Biol Cell 2002; 13 (12): 4279-4295.

8. Gimble JM, Guilak F. Adipose-derived adult stem cells: isolation, characterization, and differentiation potential. Cytotherapy 2003; 5 (5): 362-369.

9. Strem BM, Hicok KC, Zhu M et al. Multipotential differentiation of adipose tissue-derived stem cells. Keio J Med 2005; 54 (3): 132-141.

10. Fraser JK, Schreiber R, Strem B et al. Plasticity of human adipose stem cells toward endothelial cells and cardiomyocytes. Nat Clin Pract Cardiovasc Med 2006; 3: 33-37.

11. Jack GS, Almeida FG, Zhang $R$ et al. Processed lipoaspirate cells for tissue engineering of the lower urinary tract: implications for the treatment of stress urinary incontinence and bladder reconstruction. J Urol 2005; 174 (5): 2041-2045.

12. Rodríguez LV, Alfonso Z, Zhang R et al. Clonogenic multipotent stem cells in human adipose tissue differentiate into functional smooth muscle cells. Proc Natl Acad Sci USA 2006; 103 (32): 12167-12172.
13. Lee JH, Kemp DM. Human adipose-derived stem cells display myogenic potential and perturbed function in hypoxic conditions. Biochem Biophys Res Comm 2006; 341 (3): 882-888.

14. Huss FRM, Kratz G. Adipose tissue processed for lipoinjection shows increased cellular survival in vitro when tissue engineering principles are applied. Scand J Plast Reconstr Surg Hand Surg 2002; 36 (3): 166-171.

15. Charles-de-Sá L, Gontijo de Amorim NF, Dantas D et al. Influence of negative pressure on the viability of adipocytes and mesenchymal stem cell, considering the device method used to harvest fat tissue. Aesthet Surg J 2015; 35 (3): 334-344.

16. Mojallal A, Auxenfans C, Lequeux C, Braye F, Damour O. Influence of negative pressure when harvesting adipose tissue on cell yield of the stromal-vascular fraction. Bio Med Mater Eng 2008; 18 (4-5): 193-197.

17. Cheriyan T, Kao HK, Qiao X, Guo L. Low harvest pressure enhances autologous fat graft viability. Plast Reconstr Surg 2014; 133 (6): 1365-1368.

18. Bony C, Cren M, Domergue S, Toupet K, Jorgensen C, Noel D. Adipose mesenchymal stem cells isolated after manual or water-jet-assisted liposuction display similar properties. Front Immunol 2016; 6: 655.

Received June 27, 2019 Accepted July 8, 2019. 